\title{
APLIKASI SISTEM INFORMASI PERTANAHAN BERDASARKAN JENIS-JENIS HAK ATAS TANAH DI KANTOR PERTANAHAN KOTA SURABAYA II (Studi Kasus Kelurahan Genteng, Kecamatan Genteng, Surabaya)
}

\author{
Ery Abdul Baary ${ }^{1}$, Yuwono $^{1}$, Budi Doyo ${ }^{2}$ \\ ${ }^{1}$ Program Studi Teknik Geomatika FTSP-ITS, Kampus ITS Sukolilo, Surabaya, 60111 \\ ${ }^{2}$ Kantor Pertanahan Kota Surabaya II, JI. Krembangan Barat 57, Surabaya 60175, Indonesia \\ Email : ery.baary@gmail.com
}

\begin{abstract}
Abstrak
Di Kantor Pertanahan Kota Surabaya II, sistem informasi pertanahan belum diterapkan, jadi untuk melaksanakan tugasnya hanya menggunakan sebatas peta digital, maka dari itu perlu adanya sistem informasi pertanahan yang terpadu dan mutakhir untuk mendukung dan mengoptimalkan pengelolaan sistem informasi pertanahan di Kota Surabaya II.
\end{abstract}

Pada penelitian ini akan dilakukan pembuatan sistem informasi pertanahan berdasarkan jenis hak atas tanah dengan menggunakan peta digital Kelurahan Genteng, Kecamatan Genteng, Surabaya skala 1:1000, citra Quickbird 2010, database mengenai bidang tanah dan data hasil survey. Pengolahan data menggunakan software utama Autodesk Land Dekstop 2009, ArcGIS 9.3. Pembuatan program aplikasi menggunakan software Visual Basic 6.0 yang dilengkapi dengan software tambahan MapObject 2.2.

Dari hasil pembuatan Sistem informasi pertanahan di Kelurahan Genteng, Program ini mampu mengidentifikasi informasi bidang tanah mengenai jenis hak atas tanah yang meliputi 224 bidang tanah yang terdiri dari 132 bidang tanah atas hak guna bangunan, 89 bidang tanah atas hak milik, dan 3 bidang tanah atas hak pakai, serta dilengkapi dengan buku panduan sehingga dapat digunakan untuk membantu dalam pengambilan kebijakan dalam rencana pelaksanaan program inventarisasi penguasaan, pemilikan, penggunaan, dan pemanfaatan tanah.

Kata Kunci : Sistem Informasi Pertanahan, Jenis Hak Atas Tanah, Kantor Pertanahan

\section{PENDAHULUAN}

\section{Latar Belakang}

Informasi pertanahan saat ini menjadi kebutuhan pokok berbagai pihak yang harus segera terlayani. Ketersediaan informasi pertanahan merupakan salah satu unsur penting dalam tata pengelolaan negara guna perencanaan, perancangan dan pengambilan keputusan yang berkaitan dengan tanah. Sebelum era perkembangan sistem informasi dan teknologi informasi seperti sekarang ini, Indonesia telah melaksanakan Sistem Informasi Pertanahan secara konvensional, yaitu sistem manajemen basis data terpadu antara obyek grafis persil (peta) dan non-grafis (atribut persil). Sistem Informasi Pertanahan (SIP) biasa disebut juga Land Information System (LIS). Pengumpulan, pengolahan, penyajian dan analisa informasi pertanahan lengkap dengan keseluruhan atributnya, secara konvensional memerlukan banyak tenaga dan waktu, sulit dipertukarkan, sulit dimutakhirkan, terbatas dalam ragam analisa dan penyajiannya.

Sekarang, dengan perkembangan sistem informasi dan teknologi informasi, termasuk perkembangan komputer, telekomunikasi, termasuk layanan internet menjadi supply atas kebutuhankebutuhan akan informasi, termasuk informasi pertanahan. Kompilasi sistem informasi dan teknologi informasi dalam pengumpulan, pemrosesan dan pengolahan data guna menghasilkan informasi telah mendorong dan meningkatkan : efisiensi, efektifitas, keterbukaan, jangkauan pelayanan dan interaksi karena kemampuannya mereduksi ruang dan waktu. Sistem Informasi merupakan sekumpulan data dasar yang memiliki keterkaitan satu dengan lainnya dan telah melalui proses pengolahan (basis data) dengan menggunakan teknologi informasi guna : perencanaan, perancangan dan pengambilan berbagai keputusan berbasis keruangan. 
Di Kantor Pertanahan Kota Surabaya II penerapan sistem informasi pertanahan belum dilakukan, jadi untuk melaksanakan tugasnya hanya menggunakan sebatas peta digital, maka dari itu perlu adanya sistem informasi pertanahan yang terpadu dan mutakhir untuk mendukung dan mengoptimalkan pengelolaan sistem informasi pertanahan di Kota Surabaya II.

\section{Perumusan Masalah}

Perumusan masalah yang dimunculkan dalam penelitian ini adalah:

1. Bagaimana cara pembuatan aplikasi sistem informasi pertanahan berdasarkan jenis-jenis hak atas tanah di Kota Surabaya II?

2. Bagaimana hasil sistem informasi pertanahan yang dapat digunakan dan bermanfaat untuk Kantor Pertanahan Kota Surabaya II?

\section{Batasan Masalah}

Batasan permasalahan dari penelitian tugas akhir ini adalah:

1. Daerah penelitian yaitu mencakup Kelurahan Genteng, Kecamatan Genteng, Surabaya.

2. Database mengenai bidang tanah yaitu meliputi jenis hak, nomor hak, nama pemegang hak, lokasi, luas, Nomor Identifikasi Bidang (NIB), nomor surat ukur, tanggal pembuatan surat ukur, nama history pemegang hak, tanggal pembuatan sertipikat, kepala kantor Pertanahan saat penerbitan sertipikat.

\section{Tujuan Penelitian}

Tujuan dari penelitian tugas akhir ini adalah:

1. Untuk mempermudah pengelolaan sistem administrasi pertanahan dan wilayah berdasarkan data pertanahan yang terpadu di Kantor Pertanahan Nasional Kota Surabaya II.

2. Untuk mengelola basis data terpadu pertanahan sebagai data dasar dalam perencanaan dan pengelolaan wilayah kota di Kantor Pertanahan Nasional Kota Surabaya II agar Mudah dan cepat dalam analisa pantauan, evaluasi dan perencanaan pemanfaatan lahan

\section{METODOLOGI PENELITIAN}

\section{Lokasi Penelitian}

Lokasi penelitian ini dilakukan di Kota Surabaya. Namun pada penelitian ini studi kasus wilayah yaitu mencakup Kelurahan Genteng, Kecamatan Genteng, Surabaya.

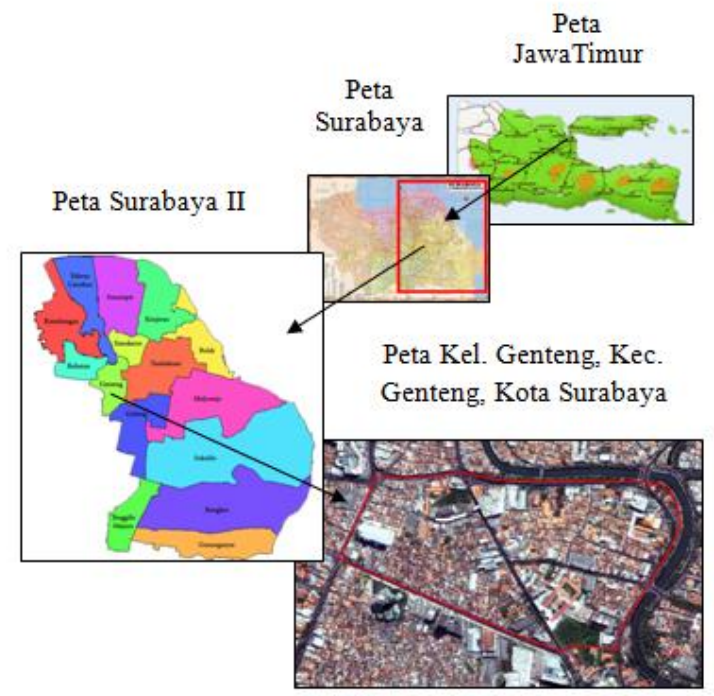

Gambar 1. Lokasi Penelitian

\section{Data Dan Peralatan}

\section{- Data}

Data yang digunakan dalam penelitian ini adalah:

1. Citra Satelit Quickbird Kelurahan Genteng, Kecamatan Genteng, Surabaya tahun 2010 yang sudah terkoreksi

2. Peta digital skala 1: 1000 Kelurahan Genteng, Kecamatan Genteng, Surabaya

3. Data non spasial : jenis hak, nomor hak, nama pemegang hak, lokasi, luas, Nomor Identifikasi Bidang (NIB), nomor surat ukur, tanggal pembuatan surat ukur, nama history pemegang hak, tanggal pembuatan sertipikat, kepala kantor Pertanahan saat penerbitan sertipikat.

4. Serta data penunjang lain misalnya berupa foto.

\section{- Peralatan}

Peralatan yang digunakan dalam penelitian ini adalah:

1. Perangkat Keras (Hardware)
a. Personal Computer
b. Kamera
c. GPS Navigasi 
2. Perangkat Lunak (Software)
a. Autodesk Land Desktop 2004 untuk proses editing peta.
b. ArcGIS 9.3 untuk pengolahan data spasial.
c. ENVI 4.6.1 untuk pemotongan citra.
d. Microsoft Access 2007 untuk pembuatan basis data.
e. Visual Basic 6.0 yang dilengkapi map object 2.2 untuk aplikasi pembuatan tampilan.
f. Photoshop CS3 untuk pembuatan design aplikasi.
g. Inno Setup Compiler untuk meng- compile program menjadi installer.

\section{Diagram Alir Pengolahan Data}

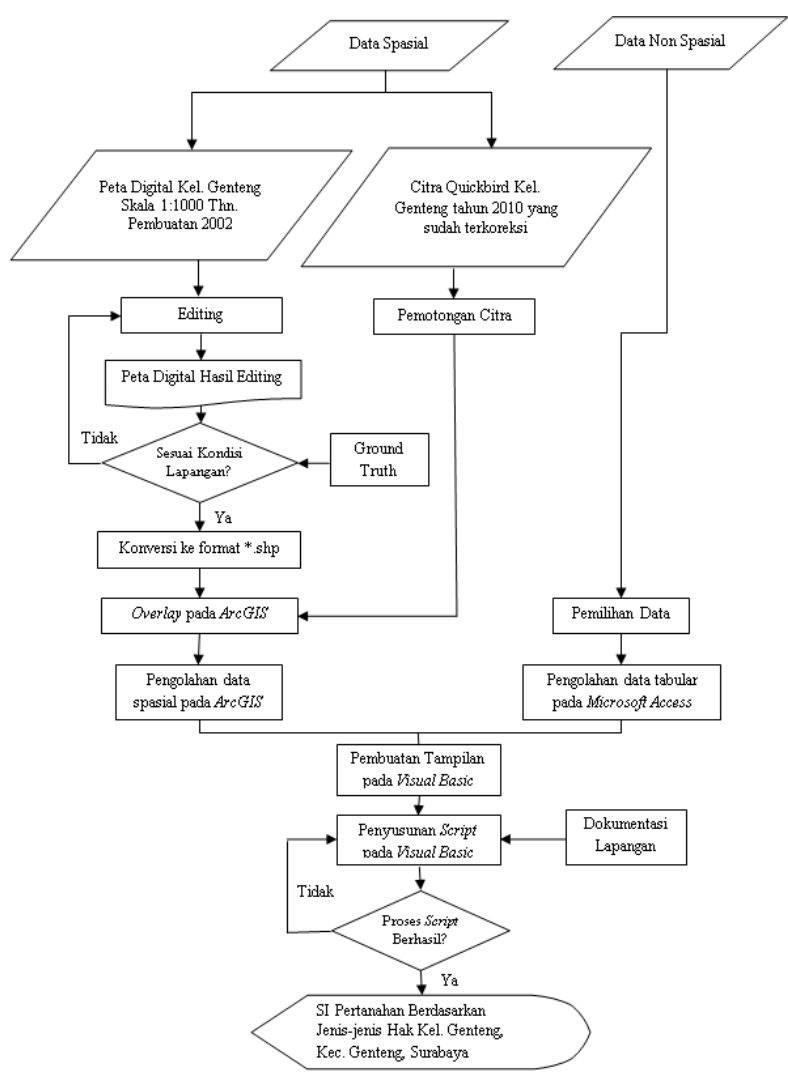

Gambar 2. Diagram Tahap Pengolahan Data

Dibawah ini adalah penjelasan mengenai diagram alir pembuatan sistem informasi pertanahan di Kantor Pertanahan Kota Surabaya II:

1. Data yang diperoleh dari Kantor Pertanahan Kota Surabaya II dipisahkan menjadi data spasial dan data non spasial. Kedua data tersebut yang nantinya akan dipadukan.
2. Data spasial berupa Peta digital skala 1:1000 tahun Pembuatan 2002 Kelurahan Genteng, Kecamatan Genteng, Surabaya Citra Satelit Quickbird Kelurahan Genteng, Kecamatan Genteng, Surabaya tahun 2010 yang sudah terkoreksi dan data non spasial yaitu jenis hak, nomor hak, nama pemegang hak, lokasi, luas, Nomor Identifikasi Bidang (NIB), nomor surat ukur, tanggal pembuatan surat ukur, nama history pemegang hak, tanggal pembuatan sertipikat, kepala kantor Pertanahan saat penerbitan sertipikat.

3. Pada tahap selanjutnya adalah editing peta. Yaitu dilakukan seleksi data mana yang akan digunakan sebagai identify dalam sistem informasi pertanahan dan pembuatan Boundary Object tiap-tiap bidang tanah. Setelah itu dilakukan exporting data ke dalam bentuk data interchange format ( $\left.{ }^{*} . d x f\right)$ untuk diolah lebih lanjut dalam ArcGIS 9.3.

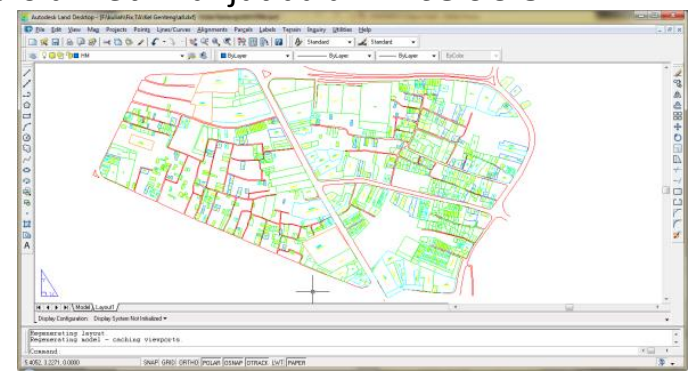

Gambar 3. Pengolahan Data di Land Desktop

4. Untuk selanjutnya dilakukan ground truth untuk pengecekan langsung ke lapangan. Jika sesuai dengan kondisi lapangan selanjutnya bisa dilakukan proses konversi format ke *.shp dan selanjutnya dioverlay antara peta digital dan Citra Satelit Quickbird.

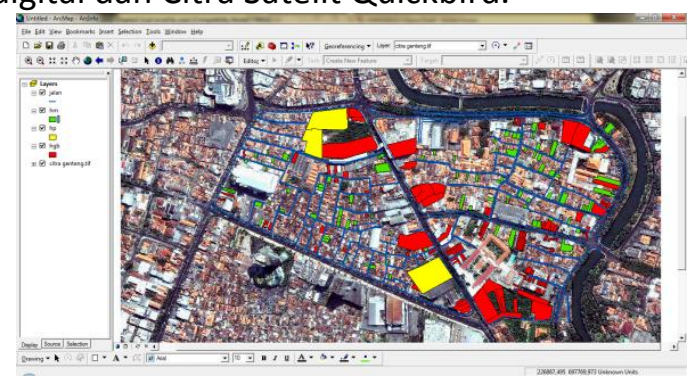

Gambar 4. Pengolahan Data di ArcGIS

5. Sedangkan untuk data non spasial yang meliputi jenis hak, nomor hak, nama pemegang hak, lokasi, luas, Nomor Identifikasi Bidang (NIB), nomor surat ukur, tanggal pembuatan surat ukur, nama history 
pemegang hak, tanggal pembuatan sertipikat, kepala kantor Pertanahan saat penerbitan sertipikat di-input ke dalam Microsoft Access sebagai basis data.

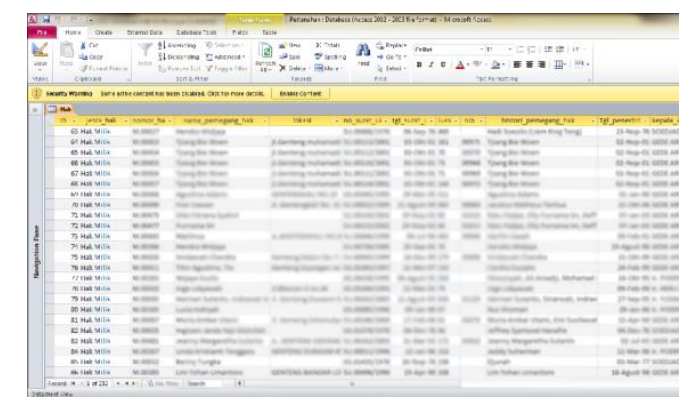

Gambar 5. Pengolahan Data di Microsoft Access

6. Dan selanjutnya hasil peta dari ArcGIS dan basis data Microsoft Accesss diintegrasikan sehingga bisa dibuat tampilan aplikasi.

7. Membuat tampilan (interface) pada Visual Basic 6.0 dengan tampilan peta menggunakan Map Object 2.2, perlu dilakukan uji script/coding, apabila belum berhasil maka harus kembali dalam proses penyusunan script pada Visual Basic.

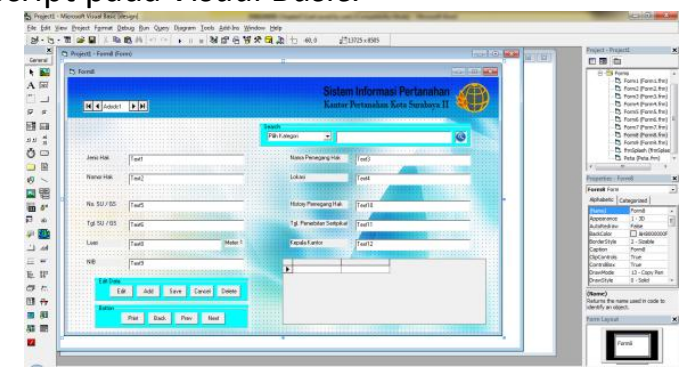

Gambar 6. Pembuatan Tampilan di Visual Basic

8. Apabila proses script/coding berhasil, maka didapat tampilan akhir berupa sistem informasi pertanahan berdasarkan jenis-jenis hak atas tanah Kota Surabaya II.

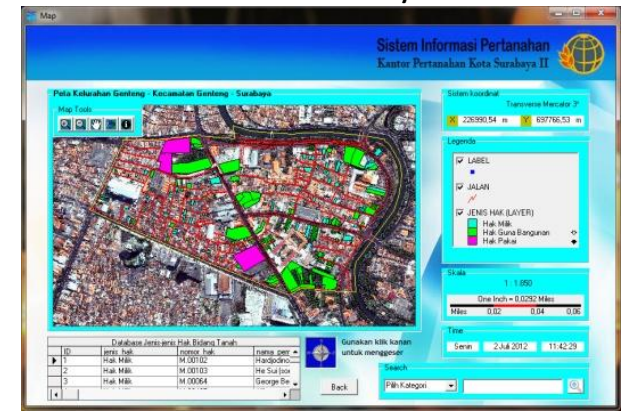

Gambar 8. Tampilan Peta Sistem Informasi

\section{HASIL DAN PEMBAHASAN}

\section{Pengolahan Data GPS}

Pada pengukuran langsung di Lapangan, didapat dari GPS Navigasi dengan sistem koordinat Transeverse Mercator $3^{\circ}$ dengan toleransi 1-3 meter. koordinat hasil groundtruth sebagai berikut:

Tabel 1. Data Koordinat GPS

\begin{tabular}{lccl}
\hline Titik & $\begin{array}{c}\text { X } \\
\text { (meter) }\end{array}$ & Y (meter) & \multicolumn{1}{c}{ Lokasi } \\
\hline 1 & 226173 & 697720 & Jl. Genteng Kali \\
2 & 226364 & 697425 & Jl. Genteng besar \\
3 & 226793 & 697346 & Jl. Genteng besar \\
4 & 226795 & 697670 & Jl. Genteng Kali \\
5 & 226703 & 697126 & Jl. Simpang Dukuh \\
6 & 225794 & 697407 & Jl. Embong Malang \\
7 & 225855 & 697663 & Jl. Blauran \\
\hline
\end{tabular}

Data koordinat GPS digunakan untuk pengecekan koordinat pada peta hasil digitasi dan hasil koordinatnya sesuai dengan pengambilan data GPS di Lapangan. Data pada tabel 1 di-ploting seperti gambar berikut.

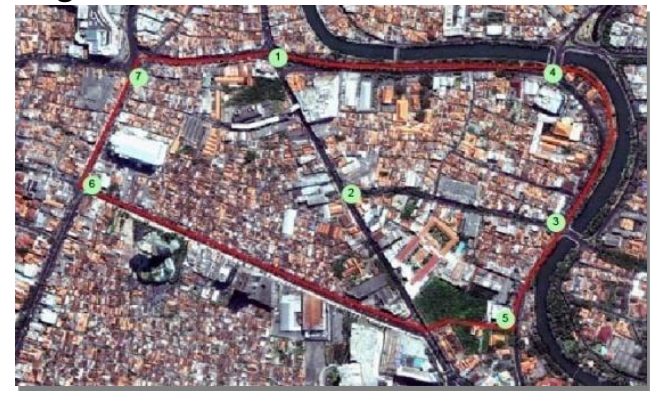

Gambar 9. Hasil ploting koordinat

\section{Pengolahan Data Spasial}

Data spasial yang ada merupakan hasil dari editing peta digital Kelurahan Genteng, Kota Surabaya tahun 2002 dengan skala 1:1000. Data spasial kemudian dibedakan menjadi beberapa Layer dan diberikan informasi didalamnya. Tujuan dibedakannya Layer adalah agar proses identifikasi pada program aplikasi lebih mudah dan teratur. Berikut adalah Layer-Layer yang ada pada sistem aplikasi:

1. Layer Label

2. Layer Jalan

3. Layer Hak Milik

4. Layer Hak Guna Bangunan

5. Layer Hak Pakai 


\section{Layer Citra Kelurahan Genteng}

Keseluruhan Layer-Layer diatas di-Overlay-kan dengan menggunakan software ArcGIS 9.3, sehingga membentuk suatu peta berdasarkan Jenis Hak Atas Tanah Kelurahan genteng, Kecamatan Genteng, Surabaya.

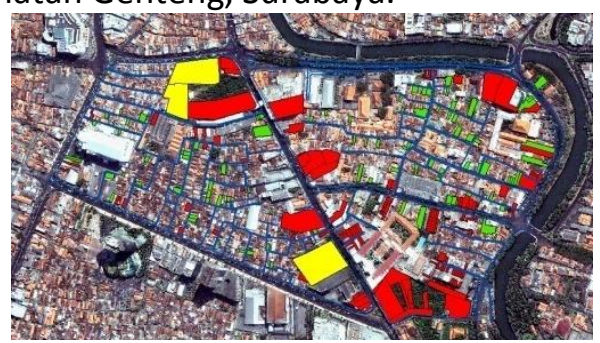

Gambar 10. Tampilan Layer

Data spasial yang sudah dibedakan menjadi beberapa Layer, selanjutnya di beri informasi sehingga dapat diidentifikasi informasinya menurut ID atau keyword yang dibutuhkan tiap Layer.

\section{Hasil Penelitian}

Pada penelitian tugas akhir ini didapatkan hasil berupa suatu program Sistem Informasi Pertanahan di Kantor Pertanahan Kota Surabaya II dengan mengambil studi kasus di Kelurahan Genteng, Kecamatan Genteng, Kota Surabaya yang menggunakan integrasi antara Visual Basic 6.0 dengan tampilan peta menggunakan Map Object 2.2 dan ditambah basis data menggunakan Microsoft Access.

\section{Pengecekan Program Aplikasi}

Tujuan dari pengecekan program aplikasi ini adalah untuk mengetahui apakah program aplikasi sudah berjalan sesuai yang dengan yang diinginkan oleh pengguna. pengecekan dilakukan dengan cara memeriksa kembali fungsi-fungsi yang ada pada program aplikasi apakah sudah bisa berjalan dan terkoneksi dengan baik atau belum.

Pengecekan Tools Penunjang Program Aplikasi:

Pengecekan ini dilakukan dengan cara mencoba tools yang ada dalam tiap form pada program aplikasi.

\section{Pengecekan Pencarian Data:}

Pengecekan ini dilakukan dengan cara memilih kategori pencarian yaitu nomor hak, pemegang hak, nib, ataupun nomor surat ukur pada combo box, dan dengan memasukkan kata kunci pada text box. Tools tersebut berada pada form database.

Hasil dari pencarian data akan ditampilkan pada tabel data yang ada Apabila data tidak ditemukan, maka tabel data akan kosong. Tabel data akan menampilkan keseluruhan data yang sesuai dengan nama kategori dan kata kunci yang dimasukkkan. Pencarian akan otomatis berjalan pada saat huruf pertama dari kata kunci ditulis.

Pengecekan Identifikasi Data:

Pengecekan ini dilakukan dengan cara menekan tombol identifikasi di halaman peta pada form utama. Setelah tombol identifikasi aktif, maka kursor dari mouse akan memiliki fungsi identifikasi objek. Pengidentifikasian dilakukan dengan mengklik objek pada layar peta sehingga akan muncul informasi detail dari objek pada form detail.

\section{Analisa}

Jenis hak atas bidang tanah di Kelurahan Genteng antara lain jenis hak milik dengan luas $65.638 \mathrm{~m}^{2}$ (521 bidang), Hak Guna Bangunan dengan luas $142.057 \mathrm{~m}^{2}$ (353 bidang), dan sisanya Hak Pakai $36.963 \mathrm{~m}^{2}$ (9 bidang). Seperti pada tabel 2 .

Tabel 2. Jumlah Jenis Hak

\begin{tabular}{lll}
\hline Jenis Hak & Bidang & Luas $\left(\mathrm{m}^{2}\right)$ \\
\hline Hak Milik & 521 & 65.638 \\
Hak Guna Bangunan & 353 & 142.057 \\
Hak Pakai & 9 & 36.963 \\
Total & 883 & 244.658 \\
\hline
\end{tabular}

Di dalam sistem informasi pertanahan ini berupa data sample yaitu hanya 224 bidang tanah yang terdiri dari 132 bidang tanah atas hak guna bangunan, 89 bidang tanah atas hak milik, dan 3 bidang tanah atas hak pakai, sesuai dengan yang sudah dipetakan oleh Kantor Pertanahan Kota Surabaya II. 


\section{Jenis Hak Atas Tanah}

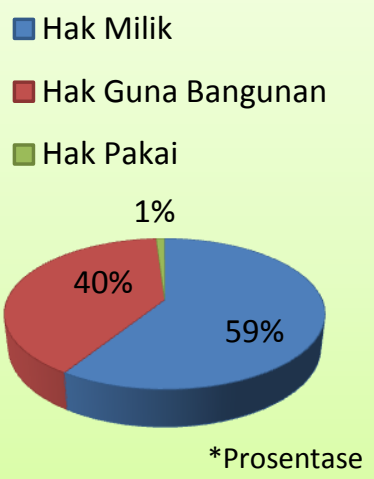

Grafik 1. Prosentase Berdasarkan Bidang Tanah

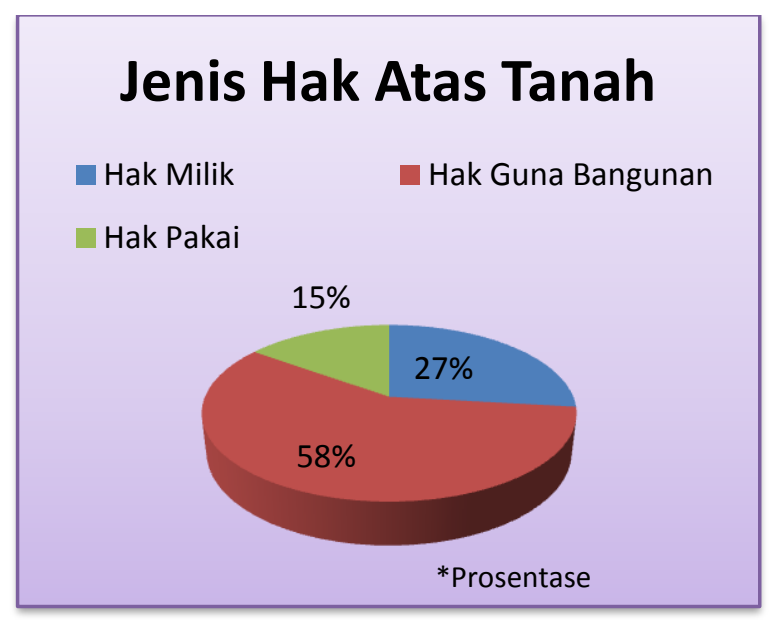

Grafik 2. Prosentase Berdasarkan Luas Tanah

Analisa Program Sistem Informasi Pertanahan:

1. Kelebihan Program

a. Pada Visual Basic bisa dengan mudah membuat sebuah program dengan mendesign interface atau tampilan program dengan Visual Basic Editor yang telah tersedia.

b. Tools utama dalam membantu pengolahan peta adalah Zoom Out, Zoom in, Pan, Zoom Extent, dan identifikasi yang kesemuanya terletak pada halaman peta.

c. Untuk tools pendeteksi koordinat bisa berjalan apabila kursor mouse berada diatas layar peta.

d. Untuk tools pendeteksi skala bisa berjalan apabila kursor mouse berada diatas layar peta dan perubahan nilai skala terjadi apabila layar peta diperbesar atau diperkecil dengan menggunakan tools zoom out atau zoom in yang ada.

e. Untuk fasilitas pencarian data, text box kata kunci tidak aktif apabila kategori pencarian belum ditentukan.

f. Pada fasilitas pencarian lokasi, pencarian lokasi aktif pada saat tombol zoom pada tabel data ditekan. Lokasi yang ditunjukkan merupakan hasil perbesaran otomatis yang langsung berlokasi ditempat data berada.

g. Bisa melakukan updating database pada aplikasi langsung.

h. Identifikasi data aktif apabila tombol identifikasi pada halaman peta sudah aktif.

i. Aplikasi mudah digunakan oleh pihak instansi BPN karena menggunakan tombol yang sering digunakan dan dilengkapi dengan buku panduan.

2. Kekurangan Program

a. Didalam program kurang diberikan layanan penggantian / up date pada peta digital atau basis data spasial. Sehingga, apabila ingin merubah harus diubah secara manual pada file.$d w g$ saja dengan mengganti dengan software Autodesk Land Desktop 2004.

b. Layar peta tidak dapat menampilkan grid dari peta.

c. Sistem koordinat tidak universal, karena menggunakan sistem koordinat TM- $3^{\circ}$

\section{KESIMPULAN DAN SARAN}

\section{Kesimpulan}

Dari penelitian tugas akhir ini dapat disimpulkan beberapa hal antara lain :

1. Aplikasi sistem informasi pertanahan ini terbangun dengan software Visual Basic 6.0 dengan tampilan peta menggunakan Map Object 2.2 dan ditambah basis data menggunakan Microsoft Access 2007 berdasarkan data pertanahan kelurahan genteng, kecamatan genteng, surabaya, yang dilengkapi dengan buku panduan operasional cara menggunakan aplikasi program.

2. Aplikasi program sistem informasi ini mampu mengidentifikasi informasi bidang tanah 
mengenai jenis hak atas tanah yang meliputi 224 bidang tanah yang terdiri dari 132 bidang tanah atas hak guna bangunan, 89 bidang tanah atas hak milik, dan 3 bidang tanah atas hak pakai.

3. Jumlah total bidang tanah berdasarkan jenis hak di Kelurahan Genteng adalah 883 bidang dengan luas $244.658 \mathrm{~m}^{2}$ antara lain jenis hak milik dengan luas $65.638 \mathrm{~m}^{2}$ (521 bidang), Hak Guna Bangunan dengan luas $142.057 \mathrm{~m}^{2}$ (353 bidang), dan sisanya Hak Pakai $36.963 \mathrm{~m}^{2}$ (9 bidang).

\section{Saran}

Bagi Kantor Pertanahan Surabaya II:

1. Didalam penggunaan program, dapat dikembangkan dengan melakukan updating data spasial dengan software yang mampu mengolah data dengan format ${ }^{*} . d w g$ dan *.shp.

2. Pada Sistem Informasi Pertanahan ini diharapkan dapat dikembangkan tidak hanya pada satu kelurahan saja tetapi dapat diterapkan pada semua wilayah Kantor Pertanahan Kota Surabaya II.

\section{DAFTAR PUSTAKA}

Arsa, H.P. 2009. “Pemetaan Dan Penyusunan Basisdata Ruang Terbuka Hijau (RTH) Kota Dengan Menggunakan Sistem Informasi Geografis". Surabaya: Teknik Geomatika FTSP ITS.

Awaludin, N. 2010. "Geographical Information Systems with ArcGIS 9.x". Yogyakarta: Penerbit Andi.

Budihardjo, E. 1995. "Sistem Informasi Manajemen", diktat KPC Pemrograman (bisnis), Bidang Pendidikan \& Pelatihan Pusat Komputer PIKSI Institut Teknologi Bandung.

Budiyanto, Eko. 2010. "Sistem Informasi Geografis dengan ArcView GIS". Yogyakarta: Penerbit Andi.

Cahyono, Edi. 2003. "Sistem Informasi Pertanahan untuk Pembangunan Gedung-Gedung di Kampus ITS Sukolilo Surabaya". Surabaya: Teknik Geodesi FTSP ITS

Chang, Kang-Tsung. 2008. "Introduction To Geographic Information System". Singapore: The McGraw-Hill Companies.

Harsono, Boedi. 2002. "Hukum Agraria Indonesia, Himpunan Peraturan Hukum Tanah". Jakarta: Djambatan.
Harsono, Djati. 2009. “Implementasi Kebijakan Sistem Informasi Dan Manajemen Pertanahanan Nasional ( Simtanas ) Di Kantor Pertanahan Kabupaten Jepara". Universitas Diponegoro Semarang.

Hilman, B. P. 2011. "Pemetaan Dan Penyusunan Basisdata Ruang Terbuka Hijau (RTH) Kota Dengan Menggunakan Sistem Informasi Geografis". Surabaya: Teknik Geomatika FTSP ITS.

McLaughlin, John D and Peter F. Dale. 1988. "Land Information Management". Oxford University Press Inc, New York.

Negara Kesatuan Republik Indonesia. 2007. “Undangundang Pokok Agraria UU No 5 Tahun 1960". Yogyakarta: Pustaka Yustisia.

Noor, Muhamad Rukhyat. 2008. “Aspek Hukum Teknologi Digital dan Dokumentasi Pertanahan". <URL: http://digilib.uns.ac.id. Diakses tanggal 28 September 2011, jam 15.00 .

Panduan Bantuan Hukum. 2009. “Jenis-jenis Hak Atas Tanah". <URL: http:// www.bantuanhukum.info . Diakses tanggal 11 November 2011, jam 12.00.

Peraturan Pemerintah Nomor 24 tahun 1997 "tentang Pendaftaran Tanah".

Prahasta, Eddy. 2001. "Konsep-Konsep Dasar Sistem Informasi Geografis". Bandung: Informatika.

Prahasta, Eddy. 2011. "Tutorial ArcGIS Desktop untuk bidang Geodesi \& Geomatika". Bandung: Informatika.

Prihandito, Aryono. 1988. "Proyeksi Peta". Penerbit Kanisius Yogyakarta.

Pusat Data dan Informasi Pertanahan. Badan Pertanahan Nasional Republik Indonesia. 2008. "Tentang Badan Pertanahan Nasional RI". <URL: http://www.bpn.go.id/tentangbpn.aspx. diakses tanggal 28 September 2011, jam 13.00 .

Sadeli, M. 2010. “Kumpulan Proyek Visual Basic 6.0”. Palembang: Maxikom.

Sangsung, Florianus. 2007. "Tata Cara Mengurus Sertifikat Tanah". Jakarta: Visimedia

Sihaloho, David. 2009. "Sistem Informasi Pertanahan Sebuah Kenyataan Dan Harapan". <URL: http://ddsihaloho.blogspot.com/. Diakses tanggal 28 September 2011, jam 15.00.

Tamtomo, J.P. 2010. "Land Information System: Sistem Informasi Pertanahan". <URL: http://tanahkoe.tripod.com. Diakses tanggal 28 September 2011, jam 15.00. 
Yudoyono, Adipandang. 2011. "Sistem Informasi Pertanahan \& Aspek Operasional
Pengelolaan Lahan Perkotaan". Universitas Brawijaya Malang. 